\title{
TINJAUAN WAKTU PELAKSANAAN PROYEK IKP RESIDENCE SORONG DENGAN METODE
} $\mathrm{LoB}$

\author{
Novri Lucky Maspaitella \\ Program Studi Teknik Sipil Universitas Muhammadiyah Sorong \\ Jalan Pendidikan No 27 Kota Sorong, Propinsi Papua Barat \\ Email : novrilucky97@gmail.com
}

\begin{abstract}
ABSTRAK
Beberapa proyek memiliki beberapa unit pekerjaan yang serupa ataupun persis sama di lapangan. Proyek multi-unit ini digolongkan sebagai aktivitasaktivitas yang berulang yang dalam banyak kasus muncul dari perincian aktivitasaktivitas umum kedalam aktivitas-aktivitas khusus. Tujuan penulisan tugas akhir ini untuk mengetahui waktu yang diperlukan ketika menggunakan metode Line of Balance sebagai alternatif model pada pembangunan proyek perumahan yang ada di Kota Sorong ditinjau dari waktu pelaksanaannya. Pada pengerjaan proyek perumahan IKP Residence yang memiliki kegiatan berulang digunakan Line of Balance. LoB adalah suatu metode penjadwalan yang pada umumnya dipergunakan untuk proyek yang memiliki kegiatan berulang metode ini mampu memperlihatkan pemanfaatan sumber daya, baik berupa tenaga kerja, peralatan maupun bahan tanpa terputus. Dengan memperbanyak jumlah lokasi/unit pekerjaan akan dapat mempercepat waktu penyelesaian proyek secara keseluruhan.
\end{abstract}

Kata Kunci : Waktu pelaksanaan, Metode LoB, Perumahaan IKP Residence. 
PENDAHULUAN

\section{Latar Belakang}

Perkembangan teknologi dari waktu ke waktu semakin pesat, tak luput pada bidang teknik sipil pula berkembangannya. Perencanaan dan pelaksanaaan suatu pekerjaan harus di lakukan dengan baik dan tepat. Tahap pelaksanaaan suatu proyek terdapat tiga aspek penting yang harus di perhatikan, yaitu biaya, waktu, dan kualitas. Suatu proyek di katakan berhasil apabila waktu dan biaya pelaksanaan sesuai dengan perencanaan serta kualitas dan kuantitas pekerjaan memenuhi syarat yang telah di tentukan. PT. Indo Karya Papua Residence merupakan perusahaan developer rumah bersubsidi, membuat rumah dengan harga terjangkau, khususkan bagi kalangan menegah ke bawah.

Tahap pelaksanaan suatu proyek konstruksi di mulai dengan penyusunan perencanaan baik waktu, sumber daya dan mutu untuk memperoleh hasil yang sesuai dengan perencanaan, di perlukan pengendalian. Penjadwalan proyek adalah salah satu dari hasil perencanaan waktu yang mampu memberikan informasi tentang jadwal atau waktu pelaksanaan dan sebagai acuan kemajuan proyek dalam kinerja sumber daya berupa peralatan, material, tenaga kerja, dan biaya serta perencanaanlamanya proyek. Saat ini di kenal metode line of balance atau LoB yang di peruntukan untuk membuat perencanaan waktu pelaksanaan proyek yang bersifat repatitif atau berulang.

Pekejaan bersifat repetitive yang di laksanakan oleh IKP Residence ini adalah berjumlah 24 unit rumah tipe 36, akan tetapi tidak memiliki penjadwalan yang bersifat sistematis, sehingga produktifitas kerja kurang optimal. Pekerjaan di laksanakan oleh dua tim dengan mekanisme pekerjaan masing-masing tim mengerjakan satu unit rumah sampai selesai kemudian pindah ke unit rumah berikut. Tim pertama terdiri dari tigabelas orang dan tim kedua terdiri dari sebelas orang. Pekerjaan ini di selesaikan dengan waktu enam bulan.

Sebagai objek studi dalam penelitian ini adalah Proyek pembangunan Perumahan bersubsidi PT. Indo Karya Papua Residence, KM. 13 Sorong Papua Barat. yang merupakan developer perumahan tipe yang sama dan berulang dengan tipe 36 sebanyak 24 unit.

\section{Tujuan Penelitian}

Penelitian ini bertujuan untuk Dapat mengetahui waktu pelaksanaan yang di perlukan ketika menggunakan metode line of balance.

\section{STATE OF THE ART}

Adapun penelitian terdahulu yang terkait dengan penelitian ini adalah sebagai berikut :

1. Yenywaty Simamora dan Waluyo Nuswantoro(2008) dalam penelitiannya tentang "Studi penjadwalan waktu dengan metode Line of Balance untuk pembangunan perumahan pasca banjir tsunami NAD (Studi kasus pembangunan perumahan di Caklang)”. Adapun tujuan dari penelitian ini adalah merencanakan pola pembangunan perumahan RI-A tipe 36 dalam waktu yang cepat dengan menggunakan metode penjadwalan yang tepat.

2. Muhammad Abrar Aulia, Aulia Hashemi Farisi, M. Agung Wibowo (2017) dalam penelitiannya tentang "Analisa penggunan metode Line of Balance pada proyek konstruksi repatitif (Studi kasus: Proyek pembangunan apartemen candiland semarang)". Adapun tujuan dari penelitian ini yaitu:

a) Mengaplikasikan model penjadwalan proyek yang sesuai bagi proyek yang memiliki pekerjaan repetitive.

b) Menganalisa kelebihan dan kekurangan LOB dari segi penggunaan metode, perhitungan kecepatan produksi, logika ketergantungan, dan hambatan pada aktivitas kegiatan.

3. Cindy A. Usyor (2016) dalam penelitiannya tentang "Perencanaan waktu pelaksanaan pada proyek berulang dengan metode line of balance (Keseimbangan Garis) (Studi kasus perumahan permata regency perumnas $\mathrm{V}$ Banjarmasin) Tujuan dari penelitian ini yaitu untuk mengetahui waktu yang diperlukan ketika menggunakan metode Line of Balance sebagai alternatif model pada pembangunan proyek perumahan yang ada di Banjarmasin ditinjau dari waktu pelaksanaannya. 


\section{METODE}

\section{Tahapan Penelitian.}

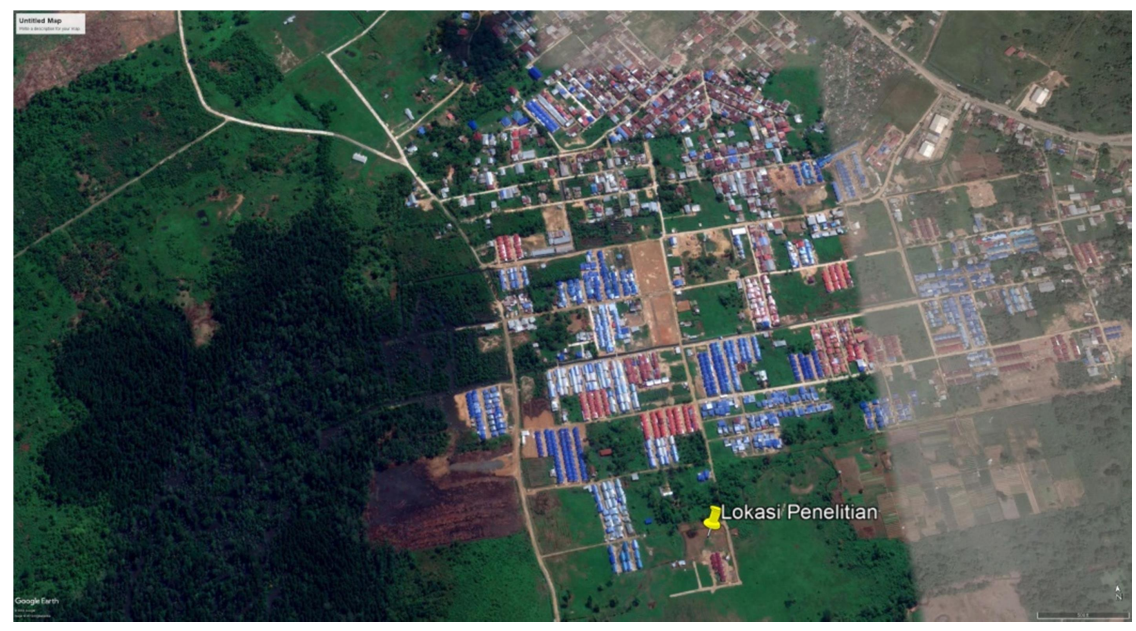

Tahapan penelitian yang digunakan adalah sebagai berikut

1. Mengumpulkan data.

2. Membuat work breakdown structure untuk pembuatan unit rumah berdasarkan data yang diperoleh. Dimana dalam pembuatan WBS ini, proyek dibagi ke dalam beberapa kelompok kegiatan per level.

3. Data aktivitas yang ada serta logika ketergantungannya.

4. Menghitung tingkat produktivitas.

5. Menghitung durasi pekerjaan.

6. Didapat waktu penyelesaian proyek.

7. Membuat diagram LoB pembangunan keseluruhan unit rumah.

Semua metode penulisan dan analisa dalam artikel ilmiah ini merujuk pada panduan penulisan tugas akhir Fakultas Teknik Universitas Muhammadiyah Sorong tahun 2014 (Pristianto, Amri, \& Rusdi, 2014).

\section{REFERENSI}

1. Artama, Wiguna \& Nurcahyono. (2012) Penerapan Repetitive Scheduling Method

Pada Penjadwalan Proyek Jalan Tubaan-Talisayan/ Dumaring, Provinsi Kalimantan Timur. JURNAL TEKNIK POMITS Vol. 1, No. 1, 1-6.

2. Budi Laksito (2005). Studi Komparatif Penjadwalan Proyek KonstruksiRepetitif

Menggunakan MetodePenjadwalan Berulang (RSM) dan Metode Diagram Preseden (PDM). Media Teknik Sipil/ Juli/ 2005.

3. Iskandar. (2008). Metode Schedule Linear (Line of Balance). htttp://iskandarmt.wordpress.com/2008/02/28/metode-schedule-linear-line-ofbalance.html.

4. Simamora, Yenywaty. (2006). Strategi penanganan secara cepat perumahan pasca bencana tsunami di nanggro aceh darussalam (NAD). Tesis Bidang Studi Manajemen Dan Rekayasa Konstruksi, Program Magister Teknik Sipil Universitas Lambung Mangkurat.

5. Wardhana, Henry. 1994. Perencanaan Jadwal Pada Proyek Jalan Lokal Dengan Metoda Penjadwalan Linear. Tesis Bidang Studi Manajemen Dan Rekayasa Konstruksi, Program Magister Teknik Sipil Institut Teknologi Bandung

6. Wiranata. Diah Parami D \& I Made Nuryawan. (2009). Penggunaan Metode 
Penjadwalan Berulang (Repetitive Scheduling Method) Pada Pengerjaan Proyek Perumahan (Studi Kasus Pada Proyek Perumahan Beranda Mumbul), Jurnal Ilmiah Teknik Sipil, Vol. 13 No. 2, 174-182, juli. 